\title{
PENGARUH KONSENTRASI BAP PADA PERKECAMBAHAN BIJI PAMELO ASAL ACEH SECARA IN-VITRO
}

\section{DIFFERENT BAP CONCENTRATIONS ON IN-VITRO SEED GERMINATION OF ACEHNESE POMELO}

\author{
Ira Handayani ${ }^{1}$, Laila Nazirah ${ }^{2}$, Ismadi $^{2}, \underset{2^{*}}{\text { Muhammad Rusdi }}{ }^{3}$ dan Rd. Selvy \\ Handayani $^{* *}$ \\ ${ }^{1}$ Mahasiswa Program Studi Magister Agroekoteknologi Fakultas Pertanian Universitas Malikussaleh \\ Kampus Reuleut, Aceh Utara, Aceh, Indonesia \\ ${ }^{2}$ Program Studi Magister Agroekoteknologi Fakultas Pertanian Universitas Malikussaleh \\ Kampus Reuleut, Aceh Utara, Aceh, Indonesia \\ ${ }^{3}$ Fakultas Pertanian Universitas Syiah Kuala, Jl. Tgk. Hasan Krueng Kalee No. 3 Darussalam, \\ Banda Aceh, 23111 \\ *Corresponding author: selvy@unimal.ac.id
}

\begin{abstract}
ABSTRAK
Pamelo (Citrus maxima (Burm.) Merr.) besar merupakan salah satu jenis tanaman hortikultura yang mendapat perhatian dari pemerintah untuk dikembangkan dan ditingkatkan produksinya karena memiliki prospek pemasaran yang baik. Permasalahan utama pengembangan tanaman pamelo Aceh adalah ketersediaan biji yang sangat sedikit atau bahkan sering dijumpai tanpa biji dan juga bijinya sulit sekali dikecambahkan dikecambahkan secara konvensional. Oleh karena itu untuk mengatasi permasalahan tersebut dapat dilakukan secara in vitro. Tujuan penelitian ini adalah untuk mengetahui pengaruh BAP terhadap keberhasilan perkecambahan biji pamelo lokal Aceh secara in vitro. Penelitian dilaksanakan di Laboratorium Kultur Jaringan Tanaman Fakultas Pertanian Universitas Malikussaleh pada bulan Desember 2018 sampai dengan Februari 2019. Percobaan ini menggunakan Rancangan Acak Lengkap (RAL) faktor tunggal. Perlakukuannya adalah konsentrasi BAP yaitu 0 dan $2 \mathrm{mg} / \mathrm{L}$ dengan 30 ulangan, sehingga didapat 60 satuan percobaan. Pada percobaan ini setiap eksplan ditanam pada botol kultur dengan jumlah 2 eksplan per botol. Data hasil pengamatan dianalisis secara statistik dengan menggunakan analisis ragam. Jika hasil uji $\mathrm{F}$ menunjukkan adanya pengaruh yang nyata antar perlakuan, maka analisis dilanjutkan dengan Uji DMRT (Duncan's Multiple Range Test) pada taraf 5\%. Hasil penelitian menunjukkan bahwa pemberian BAP dapat mempengaruhi pertumbuhan eksplan biji pamelo secara in vitro. Pemberian BAP $2 \mathrm{mg} / \mathrm{L}$ pada awal menyebabkan biji lebih lambat membentuk tunas dan akar, namun pada akhir pengamatan didapatkan biji menghasilkan tunas dan daun yang lebih banyak.
\end{abstract}

Kata kunci: pertumbuhan, eksplan, tunas akar, tunas daun

\begin{abstract}
Pamelo (Citrus maxima (Burm.) Merr.) is a horticultural commodity prioritized by the government to be developed due to its promising prospect. The scarce of available seeds resulted from seedless fruit production nowadays becomes a potential obstacle in developing pomelo conventionally. Therefore, the in-vitro assay was assigned to overcome this problem. The research was aimed at evaluating the effect of BAP application on seed germination of
\end{abstract}


Acehnese pomelo. The research was carried out in Plant Tissue Culture Laboratory, Faculty of Agriculture, Universitas Malikussaleh from December 2018 to February 2019, using Randomized Completely Design (CRD) with the only factor observed was BAP concentrations: 0 and $2 \mathrm{mg} / \mathrm{L}$. This experiment was replicated 30 times resulted in 60 experimental units in total. Two explants were planted in a culture jar. The collected data were analyzed using ANOVA, and the significant means were performed using DMRT Test at probability level 5\%. The results indicated that the application of BAP had an effect on seed germination. The application of BAP $2 \mathrm{mg} / \mathrm{L}$ has caused slower growth of buds and roots. However, last day's observation showed that this application had triggered seeds to have more buds and leaves.

keywords: growth, explant, root bud, leaf bud

\section{PENDAHULUAN}

Pamelo (Citrus maxima (Burm.) Merr.) merupakan salah satu jenis tanaman hortikultura yang mendapat perhatian dari Pemerintah untuk dikembangkan dan ditingkatkan produksinya. Pamelo memiliki prospek pemasaran yang baik dan dapat menjadi sumber pendapatan regional maupun nasional serta dapat meningkatkan gizi masyarakat.

Pamelo potensial dikembangkan karena mempunyai karakteristik yang khas yaitu buahnya berukuran besar, memiliki rasa segar dan daya simpan lama sampai empat bulan (Susanto, 2004). Selain itu Indonesia memiliki banyak plasma nutfah pamelo dengan ukuran, bentuk, warna dan rasa yang beraneka ragam. Sampai saat ini ada 17 aksesi pamelo yang telah diidentifikasi dan dilepas menjadi varietas unggulan nasional, salah satu diantaranya adalah pamelo Giri Matang dari Aceh. Hasil penelitian menunjukkan bahwa Aceh masih memiliki sebaran plasma nutfah pamelo lainnya selain Giri Matang (Rahayu, et al., 2012).

Pamelo lokal Aceh memiliki sifat unik dan khas. Ada beberapa pamelo Aceh yang sudah mulai sulit ditemukan karena masyarakat tidak tertarik membudidayakannya. Hal ini dapat mengancam kelestarian sumber daya genetik. Permasalahan utama pengembangan tanaman pamelo Aceh adalah ketersediaan biji yang sangat sedikit atau bahkan sering dijumpai pamelo tanpa biji. Selain itu biji pamelo lokal Aceh sulit sekali dikecambahkan bahkan tidak dapat dikecambahkan secara konvensional. Oleh karena itu untuk mengatasi permasalahan tersebut perlu dicari suatu teknologi alternatif.

Perbanyakan tanaman menggunakan teknologi kultur jaringan merupakan salah satu cara untuk memecahkan masalah perbanyakan tanaman yang sulit dikembangkan secara konvensional, seperti pamelo. Kultur jaringan adalah suatu teknik mengisolasi bagian-bagian tanaman (sel, sekelompok sel, jaringan, organ, protoplasma, tepung sari, ovari dan sebagainya) lalu dikulturkan pada medium buatan yang steril sehingga bagian-bagian tanaman tersebut mampu beregenerasi dan berdiferensiasi menjadi tanaman yang lengkap.

Salah satu kunci keberhasilan perbanyakan kultur jaringan adalah penggunaan zat pengatur tumbuh sitokinin. Sitokinin merupakan fithohormon yang berperan dalam pembelahan sel dan morfogenesis tunas dan akar, pertumbuhan tunas lateral dan perkembangan daun (Srivastava, 2002). Salah satu jenis sitokinin yang paling sering digunakan untuk perbanyakan in vitro adalah Benzyl amino purin (BAP). Pemberian BAP ke dalam medium kultur jaringan penting dilakukan untuk menginduksi perkembangan dan pertumbuhan eksplan. Penelitian tentang penggunaan BAP dalam media sudah banyak dilakukan, diantaranya pada tanaman jeruk 
siam (Fatonah et al., 2018), manggis (Agustina et al., 2020; Handayani et al, 2017; Handayani et al, 2013), jeruk keprok (Wijayanto, 2011), jeruk manis (Almeida et al., 2008), jeruk siam Pontianak (Agisimanto, 2005), dan pamelo (Tyas et al., 2012; Handayani et al., 2020).

Pada penelitian jeruk manis media yang paling efektif untuk menginduksi tunas adalah BA 0,5 ppm + kinetin 0,5 ppm + NAA 2. Almeida et al., (2008) berhasil menginduksi tunas adventif dari mata tunas tiga kultivar jeruk manis dengan hasil terbaik diperoleh pada media MS + BAP 1 ppm. Pada jeruk lemon "Rangpur" yang terbaik adalah media MS $+2,5$ ppm BAP. Penelitian akan membahas mengenai perkecambahan biji pamelo lokal Aceh secara in vitro. Tujuan penelitian ini adalah untuk mengetahui pengaruh BAP terhadap keberhasilan perkecambahan biji pamelo lokal Aceh secara in vitro.

\section{METODE PENELITIAN}

Penelitian dilaksanakan di Laboratorium Kultur Jaringan Tanaman Fakultas Pertanian Universitas Malikussaleh pada bulan Desember 2018 sampai dengan Februari 2019. Bahanbahan yang akan digunakan dalam penelitian ini diantaranya adalah biji jeruk pamelo lokal Aceh, alkohol $70 \%$, BAP, dan media MS. Alat-alat yang digunakan terdiri dari Laminar Air Flow Cabinet, oven, autoclaf, dan alat-alat tanam.

Percobaan ini menggunakan Rancangan Acak Lengkap (RAL) faktor tunggal. Perlakukuan adalah konsentrasi BAP yaitu 0 dan $2 \mathrm{mg} / \mathrm{L}$ dengan 30 ulangan, sehingga didapat 60 satuan percobaan. Pada percobaan ini setiap eksplan ditanam pada botol kultur dengan jumlah 2 eksplan per botol.

Sebelum ditanam, Biji pamelo dicuci lalu direndam dalam larutan Bayclin $20 \%$ selama 20 menit yang dilakukan tiga kali. Kulit biji bagian dalam dikupas lalu direndam kembali dalam lautan bayclin
$20 \%$ selama 20 menit yang dilakukan dua kali. Biji dibilas menggunakan aqudes steril dua kali. Biji pamelo steril ditanam pada media yang telah disiapkan. Penanaman biji dilakukan dengan membelah biji menjadi dua bagian kemudian biji ditanam sebanyak dua eksplan per botol kultur.

Pengamatan dilakukan selama delapan minggu. Peubah yang diamati adalah persentase tumbuh tunas, waktu tumbuh tunas, waktu tumbuh akar, jumlah tunas, dan jumlah daun. Data hasil pengamatan dianalisis secara statistik dengan menggunakan analisis ragam. Jika hasil uji $\mathrm{F}$ menunjukkan adanya pengaruh yang nyata antar perlakuan, maka analisis dilanjutkan dengan Uji DMRT (Duncan's Multiple Range Test) pada taraf 5\%. Analisis data dilakukan dengan menggunakan software SAS v9.13 portable.

\section{HASIL DAN PEMBAHASAN}

\section{Hasil}

Hasil penelitian menunjukkan bahwa perlakuan BAP berpengaruh terhadap peubah persentase tumbuh tunas. Hasil uji lanjut pengaruh konsentrasi BAP terhadap persentase tumbuh tunas disajikan pada Tabel 1 .

Tabel 1 menunjukkan bahwa perlakuan BAP memberikan pengaruh terhadap peubah persentase tumbuh tunas. Biji pamelo yang ditanam pada media MS+ BAP $2 \mathrm{mg} / \mathrm{L}$ memiliki persentase tumbuh tunas yang lebih besar daripada perlakuan tanpa BAP.

Tabel 1. Pengaruh konsentrasi BAP terhadap waktu tumbuh tunas perkecambahan biji pamelo secara in vitro

\begin{tabular}{ccccc}
\hline \multirow{2}{*}{$\begin{array}{c}\text { Konsentrasi } \\
\text { BAP }\end{array}$} & \multicolumn{4}{c}{ Persentase Tumbuh Tunas (\%) } \\
\cline { 2 - 5 } & $2 \mathrm{MST}$ & $4 \mathrm{MST}$ & $6 \mathrm{MST}$ & $8 \mathrm{MST}$ \\
\hline $0 \mathrm{mg} / \mathrm{L}$ & $1,18 \mathrm{a}$ & $1,36 \mathrm{~b}$ & $1,44 \mathrm{~b}$ & $1,49 \mathrm{~b}$ \\
$2 \mathrm{mg} / \mathrm{L}$ & $0,89 \mathrm{a}$ & $1,64 \mathrm{a}$ & $1,70 \mathrm{a}$ & $1,74 \mathrm{a}$
\end{tabular}

Keterangan: Angka yang diikuti oleh huruf yang sama pada kolom yang sama tidak berbeda nyata berdasarkan uji DMRT pada taraf 0,05 . MST $=$ minggu setelah tanam. 
Perlakuan BAP berpengaruh terhadap perkecambahan biji pamelo secara in vitro. Hasil uji lanjut pengaruh konsentrasi BAP terhadap waktu tumbuh tunas dan waktu tumbuh akar terhadap perkecambahan biji pamelo secara in vitro disajikan pada Tabel 2.

Tabel 2. Pengaruh konsentrasi BAP terhadap waktu tumbuh tunas dan waktu tumbuh akar perkecambahan biji pamelo secara in vitro

Konsentrasi Waktu Tumbuh Tunas Waktu Tumbuh BAP (HST) Akar (HST)

\begin{tabular}{ccc}
$0 \mathrm{mg} / \mathrm{L}$ & $12,94 \mathrm{~b}$ & $5,11 \mathrm{~b}$ \\
$2 \mathrm{mg} / \mathrm{L}$ & $15,76 \mathrm{a}$ & $6,50 \mathrm{a}$ \\
\hline Keterangan: & Angka & yang dikuti oleh huruf yang
\end{tabular}

Keterangan: Angka yang diikuti oleh huruf yang sama pada kolom yang sama tidak berbeda nyata berdasarkan uji DMRT pada taraf 0,05 . MST $=$ minggu setelah tanam.

Tabel 2 menunjukkan bahwa biji pamelo yang ditanam pada media yang tanpa diberi BAP ternyata lebih cepat muncul tunas dan akar. Tunas muncul pada umur 7 sampai 18 hari setelah tanam. Penampilan tunas pamelo in vitro pada umur 7 HST disajikan pada Gambar 1.
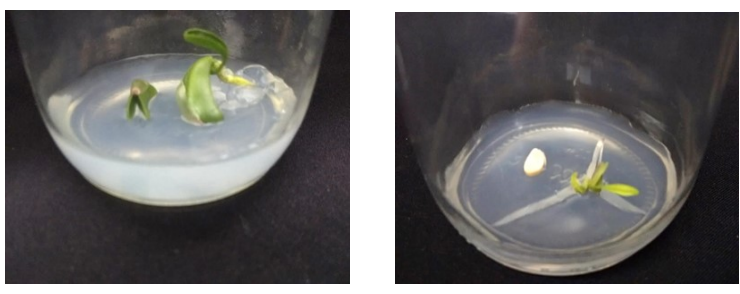

Gambar 1 pamelo secara in vitro pada umur 7 HST. a. Konsentrasi BAP $0 \mathrm{mg} / \mathrm{L}$; b. Konsentrasi BAP $2 \mathrm{mg} / \mathrm{L}$.

Gambar 1 menunjukkan bahwa pada umur 7 MST biji pamelo yang ditanam pada media tanpa BAP tumbuh berkecambah lebih cepat. Pada umur yang sama tunas pamelo pada media tanpa BAP tumbuh lebih besar daripada tunas pamelo yang ditanam pada media yang diberi perlakuan BAP.

Hasil penelitian menunjukkan bahwa perlakuan BAP berpengaruh terhadap peubah jumlah tunas 4 sampai 8 minggu setelah tanam (MST). Hasil uji lanjut pengaruh konsentrasi BAP terhadap jumlah tunas disajikan pada Tabel 3.

Tabel 3. Pengaruh konsentrasi BAP terhadap jumlah tunas perkecambahan biji pamelo secara in vitro

\begin{tabular}{ccccc}
\hline \multirow{2}{*}{$\begin{array}{c}\text { Konsentrasi } \\
\text { BAP }\end{array}$} & \multicolumn{5}{c}{ Jumlah Tunas } \\
\cline { 2 - 5 } & $2 \mathrm{MST}$ & $4 \mathrm{MST}$ & $6 \mathrm{MST}$ & $8 \mathrm{MST}$ \\
\hline $0 \mathrm{mg} / \mathrm{l}$ & $1,18 \mathrm{a}$ & $1,36 \mathrm{~b}$ & $1,44 \mathrm{~b}$ & $1,49 \mathrm{~b}$ \\
$2 \mathrm{mg} / \mathrm{l}$ & $0,89 \mathrm{a}$ & $1,64 \mathrm{a}$ & $1,70 \mathrm{a}$ & $1,74 \mathrm{a}$ \\
\hline
\end{tabular}

Keterangan: Angka yang diikuti oleh huruf yang sama pada kolom yang sama tidak berbeda nyata berdasarkan uji DMRT pada taraf 0,05. MST $=$ minggu setelah tanam .

Tabel 3 menunjukkan bahwa perlakuan konsentrasi BAP $2 \mathrm{mg} / \mathrm{l}$ memiliki jumlah tunas yang lebih banyak dari pada konsentrasi $0 \mathrm{mg} / \mathrm{l}$. Hal ini disebabkan karena penggunaan ZPT seperti BAP sangat efektif untuk merangsang pertumbuhan tunas.

Pada peubah jumlah daun, perlakuan BAP memberi pengaruh pada pertumbuhan biji pamelo secara in vitro. Hasil uji lanjut pengaruh konsentrasi BAP terhadap jumlah daun disajikan pada Tabel 4.

Tabel 4. Pengaruh konsentrasi BAP terhadap jumlah daun perkecambahan biji pamelo secara in vitro

\begin{tabular}{ccccc}
\hline \multirow{2}{*}{$\begin{array}{c}\text { Konsentrasi } \\
\text { BAP }\end{array}$} & \multicolumn{4}{c}{ Jumlah Daun } \\
\cline { 2 - 5 } & 2 MST & 4 MST & 6 MST & 8 MST \\
\hline $0 \mathrm{mg} / 1$ & 1,42 a & $1,73 \mathrm{a}$ & $1,44 \mathrm{~b}$ & $1,49 \mathrm{~b}$ \\
$2 \mathrm{mg} / \mathrm{l}$ & $0,89 \mathrm{a}$ & $1,64 \mathrm{a}$ & $1,70 \mathrm{a}$ & $1,74 \mathrm{a}$ \\
\hline
\end{tabular}

Keterangan: Angka yang diikuti oleh huruf yang sama pada kolom yang sama tidak berbeda nyata berdasarkan uji DMRT pada taraf 0,05. MST $=$ minggu setelah tanam .

\section{Pembahasan}

Perlakuan BAP yang diberikan pada media MS sebagai media dasar, ternyata berpengaruh terhadap perkecambahan biji pamelo secara in vitro. Pemberian BAP pada awalnya tumbuh tunas dan akar lebih lambat, namun ternyata dapat menyebabkan biji 
menghasilkan tunas dan daun yang lebih banyak (Tabel 1 sampai 4).

Sitokinin adalah jenis fitohormon yang dapat merangsang terjadinya pembelahan mitosis pada meristem internal. Peningkatan pembelahan sel tersebut dapat meningkatkan pembentukan jaringan berpengangkut pada tunas samping. Oleh karena itu tunas samping akan mendapatkan energi hasil metabolisme (Taiz \& Zeiger, 2002). Peningkatan konsentrasi BAP cenderung meningkatkan persentase pembentukan tunas hingga konsentrasi $2 \mathrm{mg} / \mathrm{L}$ BAP, dan menurun seiring peningkatan konsentrasi. Peningkatan konsentrasi BAP yang lebih tinggi kemungkinan akan menjadi penghambat untuk pembentukan tunas, sedangkan penurunan konsentrasi BAP yang diberikan menunjukkan bahwa BAP eksogen belum cukup memicu pembentukan tunas yang lebih banyak (Yuniati et al., 2018).

BAP merupakan zat pengatur tumbuh yang mampu merangsang pertumbuhan daun, akan tetapi semakin tinggi konsentrasi BAP yang diberikan maka jumlah daun yang didapatkan semakin sedikit. Pemberian BAP berpengaruh terhadap jumlah daun. Penelitian Fithriyandini, et al. (2015) dan Yudhanto dan Wiendi (2015) pada tanaman anggrek bulan dan kantong semar didapati bahwa pemberian BAP 2,5 $\mathrm{mg} / \mathrm{l}$ memberikan pengaruh terhadap jumlah daun.

Pada perkecambahan biji pamelo, eksplan yang dibelah dua sudah dapat membentuk tunas bahkan pada media tanpa BAP. Hal ini dikarenakan kandungan hormon endogen dan nutrisi yang terdapat dalam biji cukup tinggi sehingga dapat memacu pembentukan tunas hingga tahapan yang paling sempurna walaupun tidak ditambahkan zat pengatur tumbuh dari luar. Media MS umum digunakan untuk induksi tunas dan mengandung nutrisi yang sesuai untuk menunjang pertumbuhan optimal dari tanaman secara in vitro (Razdan, 2003).
Eksplan biji pamelo tumbuh dengan baik, membentuk tunas dan daun, serta memiliki panjang tanaman yang normal. Memanjangnya ukuran eksplan menunjukkan terjadinya pertumbuhan pada eksplan tersebut karena nutrisi dan suplai makanan terpenuhi. Hal yang sama juga di dapatkan pada penelitian Rahman et al., (2008), dimana ekspalan kotiledon Citrus maxima (Burm) Merr. cv Cikoneng di semua perlakuan mengalami penambahan ukuran atau pemanjangan eksplan sampai kotiledon bertunas. Pemanjangan juga terjadi pada eksplan pucuk jarak pagar, sebelum terbentuk kalus atau langsung membentuk tunas.

Perlakuan biji pamelo dibelah dua memiliki pertumbuhan tunas yang lebih baik di hampir semua peubah yang diamati. Pemotongan biji menyebabkan terjadi kontak antara permukaan biji dan media yang mengandung hara dan zat pengatur tumbuh tanaman. Romeida (2007) menyatakan bahwa biji manggis dibelah memiliki jumlah tunas yang tinggi. Biji pamelo yang dibelah dengan posisi telungkup dan bagian luka menghadap media menyebabkan terjadi kontak langsung antara media dengan biji pamelo yang dilukai. Oleh karena itu biji pamelo yang ditanam pada media perlakuan BAP memiliki jumlah tunas yang lebih banyak.

\section{KESIMPULAN}

Pemberian BAP dapat mempengaruhi pertumbuhan eksplan biji pamelo secara in vitro. Pemberian BAP $2 \mathrm{mg} / \mathrm{L}$ pada awal menyebabkan biji lebih lambat membentuk tunas dan akar, namun pada akhir pengamatan didapati biji menghasilkan tunas dan daun yang lebih banyak

\section{DAFTAR PUSTAKA}

Agisimanto D, Sutarto I, Supriyanto A. 2005. Induksi embriogenesis somatik jeruk siam Pontianak (Citrus suhuiensis L.) dan manis pacitan (Citrus sinensis L. Osbeck) dari biji abortus dan normal. Prosiding 
Seminar Nasional Jeruk Tropika Indonesia 2005: 122-130.

Agustina M, Maisura, Handayani RS. 2020. The Effect of Different Seed Cutting Treatments and Concentrations of BAP for the Successful In Vitro Micrografting of Mangosteen (Garcinia mangostana L.). Journal of Tropical Horticulture Vol. 3 (1) : 38-42.

Almeida RPP, Nasciemento FE, Chau J, Prado SS, Tsai CW, Lopes. 2008, Genetic Structure and Biology of Xylella fastidiosa Strain Causing Disease in Citrus and Coffe in Brazil, Appl Environ Microbiol 74(12):3690-3701

Fatonah S, Lestari W, Isda MN, Purba L. 2018. In vitro shoot regeneration of Citrus nobilis Lour. from intact seed and cotyledon explants. SABRAO Journal of Breeding and Genetics 50 (2) 168-179.

Fithriyandini A, Maghfoer M D, Wardiyati, T. 2015. Pengaruh Media Dasar dan 6benzylaminopurine (BAP) Terhadap Pertumbuhan dan Perkembangan Nodus Tangkai Bunga Anggrek Bulan (Phalaenopsis amabilis) Dalam Perbanyakan Secara in Vitro. Jurnal Produksi Tanaman. 3 (1): 43-49. doi:10.21176/protan. v3i1.167.

Handayani I, Nazirah L, Handayani RS. 2020. The Effect of BAP and IBA on In Vitro Root Cultures of Acehnese Pomelo (Citrus maxima (Burm.) Merr.). Journal of Tropical Horticulture Vol. 3 (1) : 38-42

Handayani RS, Maisura, Risky DA. 2017. Pengaruh Letak Posisi Eksplan dan Sitokinin Pada Perkecambahan Biji Manggis (Garcinia mangostana L.) Lokal Aceh Secara in-Vitro. Jurnal Agrium Vol. 14(2) :1-8

Handayani RS, Poerwanto R, Sobir, Purwito A, Ermayanti TM. 2013.
Pengaruh Batang Bawah dan Jenis Tunas Pada Mikrograftting Manggis (Garcinia mangostana L.) Secara In Vitro. J. Agron. Indonesia. 41 (1) : 47-53.

Rahman IH, Purwoko B S, Dewi IS. 2008. Perbanyakan Jeruk Besar Citrus maxima (Burm.) Merr. Kultivar Cikoneng dengan Eksplan Kotiledon dan Epikotil. Makalah Seminar Departemen Agronomi dan Hortikultura, IPB, Bogor.

Rahayu A, Susanto S, Purwanto BS, Dewi IS. 2012. Karakter Morfologi dan Kimia Kultivar Pamelo Berbiji dan Tanpa Biji. J.Agron. Indonsia 40:4855.

Razdan, M. K. 2003. Introduction to Plant Tissue Culture. 2nd Edition. Science Publisher, Inc. 377 hal.

Romeida A. 2007. Respon berbagai tipe eksplan biji manggis (Garcinia mangostana L.) pada berbagai konsentrasi benzyl amino purin (BAP) terhadap pembentukan dan regenerasi polyembrioni secara in vitro. Jurnal Akta Agrosia. 10 (2): 162-166.

Srivastava LM. 2002. Plant Growth and Development Hormon and Envirotment.Accademic Press, London.772 p.

Susanto S. 2004, Perubahan Kwalitas Jeruk Besar ( Citrus grandis (L) osbeck) yang disimpan dan dibiarkan di pohon. Hayati $11: 25-29$.

Taiz L, Zeiger E. 2002. Plant Physiology The Benyamin / Cummgs Publishing Co. Inc. New York. 672 p

Tyas KN, Susanto S, Dewi IS, Khumaida N. 2013. Konservasi Invitro Pamelo (Citrus maxima (Burm.) Merr) Melalui Pertumbuhan Lambat. Jurnal Agronomy. 41 (1) : 32-39

Yudhanto A S, Wiendi NMA. 2015. Pengaruh Pemberian Auksin (NAA) dengan Sitokinin (BAP, Kinetin dan 2ip) terhadap Daya Proliferasi Tanaman Kantong Semar (Nepenthes 
mirabilis) Secara In Vitro. Bul. Wijayanto T. 2011. Produksi bibit jeruk Agrohorti 3 (3): 276-284.

Yuniati F, Haryanti S, Prihastanti E. 2018.

Pengaruh Hormon dan Ukuran Eksplan terhadap Pertumbuhan Mata Tunas Tanaman Pisang keprok (Citrus reticulata) dan jeruk siam (Citrus sinensis) secara in-vitro yang bebas penyakit CVPD di Sulawesi Tenggara. Jurnal Agriplus Volume 21: 136-142.

(Musa paradisiaca var. Raja Bulu) Secara In Vitro. Bul. Anatomi dan Fisiologi. 3(1): 2028. 